\title{
Precautionary Principle of Science: Guideline of Ethics in Chemistry
}

\section{José Domingo Rivera-Ramírez}

Departamento de Farmacobiología, Centro Universitario de Ciencias Exactas e Ingenierías, Universidad de Guadalajara, Blvd. Gral. Marcelino García Barragán 1421, Olímpica, Guadalajara, México

Email: domingo.rivera@academicos.udg.mx

How to cite this paper: Rivera-Ramírez, J. D. (2020). Precautionary Principle of Science: Guideline of Ethics in Chemistry. Open Journal of Philosophy, 10, 374-387. https://doi.org/10.4236/ojpp.2020.103025

Received: July 25, 2020

Accepted: August 24, 2020

Published: August 27, 2020

Copyright $\odot 2020$ by author(s) and Scientific Research Publishing Inc. This work is licensed under the Creative Commons Attribution International License (CC BY 4.0).

http://creativecommons.org/licenses/by/4.0/

\begin{abstract}
Considering the two most applied ethical ideologies in science, the Value Neutrality and the Precautionary Principle, the latter is the ethical criterion that best fits the way in which chemistry has been developed and is currently executed. This work begins with a historical description of each ideology and a comparison of their fundamental statutes. After an analysis of the main problems that humanity has experienced through the chemical sciencesmassive accidents, environmental pollution and public health problems-an evaluation is made of how chemistry has applied the Precautionary Principle to evaluate every scientific and technological development and thus reestablish new criteria for the remediation and prevention of harmful scenarios to humanity and the environment. The work concludes that chemistry has established a basis for ethical exercise applying the Precautionary Principle, and this is reflected in pragmatic and objective developments as Green Chemistry, remediation and substitution technologies, and in Sanitary and Environmental Regulation.
\end{abstract}

\section{Keywords}

Ethics, Chemistry, Precautionary Principle, Value Neutrality, Environmental Pollution, Green Chemistry, Health Regulation, Drug Abuse

\section{Introduction}

The understanding of ethical boundaries that science must implement in its scientific, academic and technological developments is one of the most pressing challenges for 21st century science.

For a long time, the ethic analysis of actions and consequences of science had been restricted to selective academic circles of philosophy and it was archived in 
exhaustive intellectual exercises that rarely penetrated levels of professional and teaching practice of science (Russel, 1997; Motorina, 2014). For those who are not philosophers, the ethics of science was a complex, little crowded and arid topic, in which pure scientists, professors, professionals and technologists had little reliable and formal interest, and when it came to having it, little progress and valuable learning was achieved due to the lack of formal study methodologies in philosophy (Wolpe, 2006).

During the second half of the 20th century, with the advancement and diversification of the uses of knowledge and technique and also the findings of 1) mismanagement of natural resources, 2) measurement errors and data emission, 3) damage to public health and the environment, and 4) massive accidents; scientists, technologists and professionals realized the need to establish specific and pragmatic ethical criteria for scientific and professional practice (Resnik \& Elliott, 2016). Thus new scientific work modes emerged such as 1) standardization of measurement methods and data processing, 2) health, environmental, professional and financial regulations, and 3) accident and disaster prevention. Therefore, efforts were no longer directed solely at scientific, academic, technological or ideological development, but rather also at the correct interpretation, regulation and application of knowledge and technique. It is difficult to establish whether these new criteria were motivated by ethics, but they are certainly within its limits of study.

Of the two most antagonistic ideologies in the ethics of science-Value Neutrality and Precautionary Principle-in this article I will demonstrate that chemistry as a natural and experimental science, is the one that best fits and implements the Precautionary Principle. This is a consequence of the historical development of this science, which in turn has been notably influenced by the need to remedy first, and then prevent negative consequences on humans and other living beings, natural resources and recently financial and economic resources.

This work begins with a documentary review of the main ideas of both ethical lines, their historical and ideological origins, and a proposal of why chemistry, in many cases without knowing it, leaves neutrality in value judgments and builds principles of analysis and prediction of catastrophic consequences to avoid them as far as possible. Thus, it adjusts to the Precautionary Principle of Science.

\section{Two Ideological Lines of Ethics in Science}

\subsection{Value Neutrality}

In the mid-seventeenth century-after the disappearance of Natural Theology and Alchemy, and along with Experimental Philosophy-it initiated the original version of science as we know it today, the Natural Philosophy ${ }^{1}$. With this term, all the arts and sciences taught in the schools of philosophy were known generically, and covered mathematics, philosophy, statistics, mechanics and geometric

${ }^{1}$ With the development of electromagnetism and thermodynamics, by the middle of the 19th century Natural Philosophy would become Physics. 
optics (Schummer, 2004).

Almost on a par with its ideological and technical developments, Natural Philosophy sought to delimit its scope and, in the opinion of such philosophers, to distinguish itself from other human activities such as art, religion or politics. The first such ideological delimitation occurred when in 1660 king Charles II of England approved that members of the College of Physics and university professors of mathematics, physics, and natural philosophy meet weekly in what has since been known as the Royal Society (Spratt, 2003; Kovac, 2006). Although this group, which had been meeting since 1645, had an ideological tradition in which were not allowed the study of subjects such as divinity and religion; state, political or current affairs; morality, metaphysics, grammar, rhetoric or logic; with the approval of the king and the moral authority of its members, this ideology became the norm for the subsequent scientific exercise in England and practically throughout Europe.

Philosophical support for this way of thinking was provided by the so-called Enlightened Philosophers such as Kant (1724-1804) and Condorcet (1743-1794) even later by Neurath (1882-1945) - who saw modern science as the triumph of reason on dogmatic religion and superstition, coming to affirm that the progress of science and technology would have a profound positive impact on society and that the application of scientific methods to society itself would automatically lead to happiness, freedom, political and social justice, and the solving of human problems like warfare (Leach, 1968).

In the following decades, mathematical and physical models that described Nature "unquestionably" were established in Europe. These new statutes relegated to the second or third level the importance of man's intervention in natural processes. It was easy to establish that the trajectory and periodicity of the planetary orbits, the flow and transformation of energy, the composition of matter or the electromagnetic laws, were not disturbed by social and human needs-such as temper or nationality of its discoverers; for the revolutionary joust that was occurring in American or African colonies; or by the quantity of sugar and cocoa that had to be cultivated to satisfy the demand of the European market of the time. Thus, the central dogma of ethics in science, The Valuable Neutrality of Science, was established:

Science does not or should not have ethical or moral value judgments, since science and scientists are only instruments through which the structure and language of nature is revealed. The results generated by science are useful or harmful depending on the intentions or objectives of whoever decides to use them (Olivé \& Pérez-Tamayo, 2012).

By the nineteenth century and until about the middle of the twentieth century, both philosophers and scientists were convinced that scientific claims were universally valid and that the origins of scientific developments had no moral consequence (Gavroglu, 2009).

Some authors attributed to Vienna Circle, which represented Logical Positivism, the consolidation of Value Neutrality of Science as a form of ethical exercise 
in science (García \& Arango, 2010; Stump, 2002). By reviewing its statutes ${ }^{2}$ and the historical and social context in which it was developed-First and Second World Wars, and the first glimpses of machinery of mass destruction-it is inevitable to think that the scientists and philosophers of the time fought to prevent that science and scientists will work at the mercy of sides and circumstantial ideologies, and optimistically they saw that a neutral science would transcend conflicts, ideologies and struggles. However, many of the supporters of this ideology denied that there was a direct connection between science and values, and that if there were, it would be partial. Vienna Circle itself has commonly claimed to demonstrate that the human sciences have more impact on society than the exact sciences, and that it was difficult to imagine the value neutrality of the human sciences as it is to imagine the social relevance of the exact sciences (Stump, 2002). For example, Schlick included social science ethics as an independent category, arguing that ethical concerns were the result of people holding certain principles, their desires, and how to satisfy them (García \& Arango, 2010).

Thus, the Value Neutrality of Science seemed to offer universal objectivity, neutrality, legitimacy and credibility to any scientific position; attacking it would condemn those who did so for defending obscurantist, retrograde and irrational ideas. This, however, would not be useful and valid when scientists had to repair or prevent many of the subsequent situations and phenomena derived from social uses of science. In different situations, supporters of Value Neutrality would seem to have interpreted and exercised it as a pretense to demonstrate a kind of humanistic side of science and to lessen the social responsibility of scientists, but not as a regulatory mechanism for generation and use of knowledge (Verdugo-Serna, 1997).

\subsection{The Precautionary Principle}

After the 1960s many historians and sociologists began to question the universal validity of the statutes of science and that frequently they did not have an acceptable moral meaning. Many thinkers began to affirm that although throughout history science has been dedicated to the understanding of reality and nature, the perception and dimensioning of these depends on the characteristics of every period, such as culture, warfare and jousts; the state of public health, the state of knowledge, the degree of literacy of the population, economic phenomena such as migration, industrialization or politics; and that these in turn were not frequently the product of philosophical or scientific interpretation, but also of social activities that at that time sought to satisfy what people considered "normal”, "logical”, “aesthetic" or "correct" (Gavroglu, 2009).

Several scientific-social phenomena led to questioning the Value Neutrality of Science as the guiding axis of the ethics of science; for example: 1) the undeniable consumption of knowledge and technique of the two World Wars of the 20th ${ }^{2} 1$ ) Philosophy is objective, genuine knowledge, 2) Unification of knowledge, philosophy and science are continuous, 3) Updating philosophy to recent scientific advances, 4) Defense of the internationalism of philosophy and 5) Promotion of a conception from a scientific world. 
century (Bullard et al., 1975; Chin, 2019), 2) the recently started wave of massive consumption of drugs and narcotics in industrialized countries (Duarte, 2005), 3 ) the recently inaugurated industries of dyes, oil, chemical and polymers (Morris, 2007) and 4) the first documented findings of damage to public health from emissions and effluents, by everyday products, by certain processed foods and by the misuse and design of drugs and medicines. In addition to the above, in the mid twentieth century, the state of scientific knowledge and the culture-societyscience trinomial had become so diversified that scientific sub-disciplines or multidisciplinary study groups emerged with the intention of expanding the capacity to observe, measure or document Nature or the consequences of society-science interaction. These new sub- or multi-disciplines were represented by second or third generation scientists, disciples of the defenders of Value Neutrality, and had new objects and methods of study, have made new findings and generated new principles of scientific exercise.

Thus, the Value Neutrality of Science was diluted until it became diffuse and obsolete. For many scientists, teachers and technologists, the discourse of this ideology was useful only in texts and was significant as acceptance requirement in scientific societies, but it was not possible to apply it in problem solving or even in the publication of new results and findings. Today it is evident that it is no longer valid to launch a scientific proposal arguing the supreme interest of knowledge without noticing the moral impact that new techniques, data, measurements or developments could bring. In this sense, it has been common to justify new scientific and technological approach as a benefit to society, arguing that the ability to observe or measure any phenomenon will be improved or the benefit of some product, service or technique will be increased.

These arguments represent the Precautionary Principle of Science, an ethical ideology that practically opposes the ideas of Value Neutrality, but that unlike this, was not originated as a proposal of ideological distinction, but as a remediation and prevention mechanism of the unfavorable consequences that at the time were generated by the conscious or unconscious use of the same science.

The Precautionary Principle has been defined as:

A new standard of behavior that can be legitimately used to confront scientific uncertainty about possible damages regarding environmental protection, and public health (Godard, 2013).

It was first mentioned in the Rio Declaration in Principle 15 (Cafferatta, 2004) and in the Maastricht Treaty. It has been classified as a tool to identify potential risks and threats, which refer to the possibility of something scientifically uncertain, not proven, and not sufficiently measured. It has also been considered useful in carrying out the prevention of known risks that can be assessed. Both aspects would offer rational bases for social security policies (Godard, 2013).

When it is necessary to particularize which events or misuses of knowledge generated a negative consequence for humanity or the environment, it is not difficult to conclude that many of them had to do with the use of substances and therefore with chemistry. The historical origin of the Precautionary Principle of 
Science can be explained by understanding how chemistry had developed, implemented, and regulated its different areas of application. Just as Value Neutrality can count genuine scientific statements supporting it, the Precautionary Principle has its own in chemistry. During the second half of the twentieth century emerged professional and scientific practice standards whose intention was to prevent and remedy the environmental impact and regulate the use of natural, scientific, intellectual and human resources, thus can be distinguished: 1) safety and hygiene protocols in laboratories and industries, 2) health and pharmaceutical regulations, 3) Green Chemistry and 4) Quality by Design. The origin of each of these manifestations is explained below.

\section{The Historical Development of the Precautionary Principle in Light of Chemistry}

While in the seventeenth century Natural Philosophy manifested its intellectual power and its rigorous methods, chemistry, as an area of independent knowledge, hardly emerged from its first formal contributions. Coming from the alchemist tradition which was typically covered by cosmological and anthropological interpretations, chemistry was born from the need to solve problems directly linked to human activities and needs-artisans at the time, and industrialists, doctors, pharmacists and militias later-.

The fact that chemistry has developed its knowledge and technique on a more social level, caused that putting into practice its postulates had more immediate consequences, both favorable and unfavorable, for humanity. This caused that chemistry had developed its own philosophical and ethical profiles. Many philosophers argue that the reason why chemistry at that time was not part of Natural Philosophy, was because it was not developed and not even defined as science; versions prior to chemistry-apothecary art, ceramic art, metallurgy and mineralogy, certain aspects of cellular function and the origin of life-were not considered sciences due, first, to their experimental nature, and second, that they did not apply mathematics in their reasoning and therefore their results could not be predicted. These precursor versions of chemistry were taught in medical schools, when they applied, or were trades in which their practitioners, however, began to achieve great mastery and development of knowledge and technique (Chamizo, 2010).

\subsection{Abuse of Substances}

One of the first manifestations of the precautionary sense of substance use was the observation that the German Friederich Sertüner (1783-1841) made after test on himself the effects and addiction to morphine (Duarte, 2005):

"I consider it my duty to draw attention to the terrible effects of this new substance, so that a calamity can be prevented."

Subsequent, apparently reliable, motivations to better understanding of the biological effects that morphine had on the human body, the need to care for 
those wounded in the armed conflicts ${ }^{3}$, and perhaps the lack of attention to Sertüner's warnings triggered that in the following years, large and permissive investments were deployed for the use and marketing of this substance in Germany and the United States (Schmitz, 1985). At the time, the lack of knowledge of dosage aspects and the need to ease pain in wounded soldiers, led to the generation of habitual consumers and addicts.

With a geometric escalation, after World War II the consumption of narcotics, substances of abuse and non-prescribed drugs has become almost cultural (Telles, 2019; Hull, 2018; García et al., 2018; Hider-Mlynarz, Cavalié, \& Maison, 2018). As an example, in 2015 in Western Europe, the prevalence of consumption dictated that in a period of thirty days one in three people had had an episode of excessive consumption of alcoholic beverages and one in five had used tobacco daily. On the other hand, in a period of one year, $7 \%$ had consumed cannabis, $0.6 \%$ amphetamines, $1.1 \%$ cocaine and $0.4 \%$ opioids (Atzendorf, Rauschert, Seitz, Lochbühler, \& Kraus, 2019).

Beyond the socio-political justifications and facets attributed to substance abuse and addiction, this remains an outstanding debt that science, and especially chemistry, have with mankind (Herzberg, Guarino, Mateu-Gelabert, \& Bennett, 2016). It is not difficult to appreciate that many of these substances are the direct result of the chemical and synthetic knowledge that we have generated over the last 200 years. With research projects carried out without data and results registration controls, and without appropriate ethical training in its executors and shareholders, scientist had contributed to place many regions of the world at the mercy of the illegal trade in substances (Lafferty, Hunter, \& Marsh, 2006; Zee, 2009). The efforts to remedy the unfortunate results of this phenomenon are not minor or negligible, however it is necessary to adopt a scientific culture of greater responsibility and prevention. In the first developments in the nineteenth and part of the twentieth centuries there were no records or findings of the consequences of substance use in humans, but today we do have them; nowadays pretending to carry out scientific developments of new substances at the level of synthesis or isolation from natural sources, without an exhaustive evaluation of their biological and therapeutic effects or, on the other hand, pretending that politicians or businessmen, or even society, take right decisions about its use and commercialization, is a naivety whose consequences affect the same science.

\subsection{Environmental Pollution}

The second great phenomenon related to the use of substances, whose proportions and consequences affect all of nature, was environmental pollution. A natural consequence of the existence of humanity is the modification of the environment and the use of resources to satisfy survival needs, however, with the improvement of technique, with the appearance of industrial production and

${ }^{3}$ Crimean War (1854-1856), Prussian-Danish War (1866), Franco-Prussian War (1871-1872), and American Civil War (1861-1865), First World War (1914-1918). 
science, this modification and consumption have grown and diversified to such a degree that they put at risk the subsistence of all living beings on the planet.

As early as 1306, King Edward I of England banned the burning of coal in London because the smoke polluted the city's air (CCPS, 2006). During the decades after the Industrial Revolution, documentation and observations on environmental pollution began (Tarlock, 2009; Lucas, 2003; Kasa, 2008), but it was not until the first fifth of the 20th century when it was unequivocal that the indiscriminate use of substances in human activities had a profound impact on the environment and public health.

Consider the next example. Between 1915 and 1925 the discovery of the anti-knock properties of tetraethyl lead (TEL) allowed its use in gasoline and promoted the growth of the Automotive Industry. The demand for this compound grew so much that by 1950 the production of TEL in the United States reached 100,000 cubic tons per year, and by 1970 it had increased to 270,000 tons per year and it was 375,000 tons per year in the world. It has been estimated that during those 50 years $7.2 \times 10^{9}$ liters of leaded gasoline were produced per year, one of the most produced chemicals in history! TEL had been warned about the damage to the atmosphere since 1922, but it was the intoxication of production operators that placed it in the public scrutiny, however, for decades the intervention of commercial interests prevented that studies of toxicity and safety were impartial and it was not until the 1990's that there was a reliable environmental regulation for the production and use of TEL in gasoline (Nriagu, 1990).

When considering other substances of mass production and distribution and that have also caused problems of environmental contamination and public health (Table 1), their stories run parallel to that of TEL, thus we can group their social impact into 6 stages:

Table 1. Most polluting substances to the environment.

\begin{tabular}{|c|c|c|c|c|c|}
\hline Compound & $\begin{array}{l}\text { Implementation } \\
\text { Year }\end{array}$ & $\begin{array}{l}\text { Recall } \\
\text { Year }\end{array}$ & $\begin{array}{l}\text { Damage } \\
\text { Caused }\end{array}$ & $\begin{array}{l}\text { Maximum } \\
\text { Production }\end{array}$ & Regulation \\
\hline $\begin{array}{l}\text { Tetraethyl } \\
\text { Lead }\end{array}$ & 1920 & 1990 & $\begin{array}{l}\text { - Pollution } \\
\text { - Toxicity }\end{array}$ & $7.2 \times 109 \mathrm{~L}$ & $\begin{array}{l}\text { Section } 211 \text { of the } \\
\text { Clean Air Act }\end{array}$ \\
\hline $\begin{array}{l}\text { Asbestos } \\
\text { (Barlow et al., } \\
\text { 2017) }\end{array}$ & 1850’s & 2005 & $\begin{array}{l}\text { - Cancer } \\
\text { - Silicosis } \\
\text { - Asbestosis }\end{array}$ & $5,000,000$ ton & $\begin{array}{l}\text { Basel Convention } \\
\text { on the Control of } \\
\text { Transboundary } \\
\text { Movements of } \\
\text { Hazardous Wastes } \\
\text { and Their Disposal }\end{array}$ \\
\hline $\begin{array}{l}\text { Polymers } \\
\text { (Setzen, 2008) }\end{array}$ & 1880’s & In use & Pollution & $\begin{array}{l}348,000,000 \\
\text { ton/year }\end{array}$ & Unfinished \\
\hline $\begin{array}{l}\text { Cromates (Coet- } \\
\text { zee et al., 2018) }\end{array}$ & 1890’s & In use & $\begin{array}{l}\text { - Cancer } \\
\text { - Pollution }\end{array}$ & $\begin{array}{l}18,000,000 \\
\text { ton/year }\end{array}$ & Unfinished \\
\hline $\begin{array}{l}\text { Chlorofluoro } \\
\text { carbonates } \\
\text { (Hoffman \& } \\
\text { Wells, 1989) }\end{array}$ & 1928 & 1995 & $\begin{array}{l}\text { Degradation } \\
\text { atmospheric } \\
\text { ozone layer }\end{array}$ & $1,200,000$ ton & $\begin{array}{l}\text { Montreal Protocol on } \\
\text { Substances that Deplete } \\
\text { the Ozone Layer }\end{array}$ \\
\hline
\end{tabular}


1) XIX and XX centuries intersection: Discovery of a technological application for a new substance.

2) First fifth of the 20th century. Technology development for large-scale production or processing, funded by a startup in the industrial sector.

3) Second fifth of the 20th century. Export, establishment of trade routes and distribution points in strategic regions of the planet.

4) Third fifth of the 20th century. Accumulation of evidence of the negative impact on the environment and on public health.

5) Fourth fifth of the 20th century. Initiation of efforts to regulate or prohibit the use of the substance, establishment of personal protection measures and accident prevention.

6) Intersection of the XX and XXI centuries. Establishment of regulation, measurement of effects caused by the substance, initiation of research into remediation or alternative and substitute technologies for the substance. Application of the Precautionary Principle in Chemistry.

As mentioned above, the Precautionary Principle of Science was not born as an ideological or philosophical badge, but as a mechanism for regulation and remediation of the effects of science as gets involved in society. In case of chemistry, the Precautionary Principle is the reflection of the state of knowledge in every age; as evidence, technique and understanding of chemical phenomena are accumulated, institutions, professionals, researchers and companies readjust the evaluation and approval criteria of every development, and thus it is possible to generate science, products and services that are safer and more efficient.

\subsection{Drugs and Health Regulation}

The Thalidomide Tragedy is one of the hardest blows that science has taken (Strömland, Philipson, \& Anderson, 2002). Although there have been other sobering events, for chemistry so few have revealed the deficiencies that technological developments can have and the profound damage that can be caused to human beings by it. This event separated the chemical-biological sciences from the thesis of the Value Neutrality of Science and promoted one of the most genuine manifestations of the Precautionary Principle: Sanitary Regulation.

Until before discovering that in the thalidomide the $R$ enantiomer had a therapeutic effect and the $S$ enantiomer a teratogenic effect, stereochemistry was considered a mere curiosity in organic molecules and at most a characteristic of molecular recognition mechanisms in metabolic pathways. However, after demonstrating that approximately 10,000 people had been affected, the entire ideological and synthetic machinery of chemistry was rebuilt and questioned, giving rise to new lines of work and planning.

One of the most outstanding consequences in this field was the establishment of criteria, lines of research and even evaluation institutions to prevent and remedy consequences similar to those of thalidomide. In a few years, the development of guidelines and regulatory standards has made possible to evaluate every 
stage of the development and commercialization of a compound with biological activity, as well as establishing detection methods and safety limits for potentially harmful compounds. Today it is unthinkable to test the biological activity of a mixture of stereoisomers without first having done the same with every pair $D, L$ or disteroisomers.

In the same way, the stability, structural identification and biological safety studies of new drugs, their related compounds, their raw materials or synthetic reactants and catalysts, are so rigorous that today it is necessary to demonstrate to authorities spectroscopic profiles, purification methods, and toxicity and safety limits tests on final products, in order to demonstrate that there is no cross-contamination. The intention of these regulatory requirements is to establish that the consumption of a new drug is safe and effective against the condition for which it was designed and developed and that there is no possibility of poisoning or non-expected secondary effects. Once on the market, pharmacovigilance committees continue to record information that may be useful in detecting long-term effects, or other therapeutic uses (ICH Harmonised Tripartite Guideline, 2006).

\subsection{Green Chemistry}

Finally, another manifestation that is the consequence of the fact that more scientists consider the Precautionary Principle as a form of execution of science is the ideology of Green Chemistry (Anastas \& Warner, 1998). In order to avoid that the activities of organic synthesis and molecular design as they have been carried out up to now, continue generating waste and effluents that harm humanity and the environment, in their 12 statutes Anastas and Warner seek to establish new guidelines for research and evaluation of the benefit that a new chemical proposal could bring. It is good to say that although these authors pointed out Green Chemistry conceptually, they are not its only representatives, since it encompasses other contemporary manifestations whose purpose is to improve the methods of obtaining substances with the least environmental impact and the maximum possible benefits. Thus, it is possible to cite biocatalysis (Britton, Majumdar, \& Weiss, 2018), microwave chemistry (Thomas-Hillman, Laybourn, Dodds, \& Kingman, 2018), mechano-chemistry (Leonardi, Villacampa, \& Menéndez, 2018), solvent-free synthesis (Paseta, Potier, Sorribas, \& Coronas, 2016), green pharmacy (Kümmerer, 2007), micellar catalysis (Lipshutz, Gallou, \& Handa, 2016), among others.

\section{Conclusion}

Science, and particularly chemistry, is no longer conceived as they were 100 years ago. At the time, the number of people making and consuming chemistry was noticeably less and less complex than now. During this time, our ability to measure and evaluate the consequences of the development and use of knowledge have improved. Today it is possible to predict unfavorable scenarios and 
their prevention or resolution with a high degree of reliability.

On the other hand, chemistry is the only science that is carried out at an industrial level-in any of its variants: pharmacy, cosmetics, engineering, food production-and whose developments reach practically the entire population and Nature. In this sense, adopting an ethical-scientific conduct of simple expectation or delegation of responsibilities when using knowledge and technology is not an adequate development strategy. In the case of products and services provided by chemistry, permanent scientific advice is necessary to carry out evaluations, measurements and prevention of accidents and catastrophes.

Thus, the Precautionary Principle of Science applied in chemistry, rather than a rigid ideological protocol, is a guide for adequate decision making. Still today many philosophers and scientist argue that the value of science is provided by external actors of science and that attempts to prevent undesirable situations are an irrational and endless practice in which a satisfactory conclusion could not be reached, since there will often be those who will misuse science ${ }^{4}$. However, a science without users to design or execute it properly would make no sense or advance, are not unceasing premises of science to improve understanding of nature or quality of human life? In this sense, the evaluation of the worst possible scenario would allow us to identify scenarios of less negative impact and thus establish preventive measures and, where appropriate, corrective measures; this includes of course the education and training of the scientists that will be able to do it.

Finally, he Precautionary Principle of Science is the guide over the chemical sciences have been developed in the last century, its existence is not an ideological label, but a necessity of current science. If science were strictly neutral, searches such as the cure of diseases, energy sources, technology and even knowledge could not be generated.

\section{Acknowledgements}

J. D. R. R. thanks CONACyT for financial support as CANDIDATE FOR NATIONAL RESEARCHER.

\section{Conflicts of Interest}

The author declares no conflicts of interest regarding the publication of this paper.

\section{References}

Anastas, P., \& Warner, J. C. (1998). Green Chemistry: Theory and Practice. New York: Oxford University Press.

Atzendorf, J., Rauschert, C., Seitz, N., Lochbühler, K., \& Kraus, L. (2019). The Use of Alcohol, Tobacco, Illegal Drugs and Medicines: An Estimate of Consumption and Substance-Related Disorders in Germany. Deutsches Ärzteblatt International, 116, 577-584.

${ }^{4}$ Some authors call this Extreme Catastrophism. See Godard, 2013. 
Barlow, C. A., Sahmel, J., Paustenbach, D. J., \& Henshaw, J. L. (2017). History of Knowledge and Evolution of Occupational Health and Regulatory Aspects of Asbestos Exposure Science: 1900-1975. Critical Reviews in Toxicology, 47, 286-316. https://doi.org/10.1080/10408444.2016.1258391

Britton, J., Majumdar, S., \& Weiss, G. (2018). Continuous Flow Biocatalysis. Chemical Society Reviews, 47, 5891-5918. https://doi.org/10.1039/C7CS00906B

Bullard, E., Lovell, B., \& Deacon, G. (1975). The Effect of World War II on the Development of Knowledge in the Physical Sciences. Proceedings of the Royal Society of London. Series A, Mathematical and Physical Sciences, 342, 519-536. https://doi.org/10.1098/rspa.1975.0042

Cafferatta, N. A. (2004). El principio precautorio. Gaceta Ecológica, 73, 5-21.

CCPS, Appendix (2006). Safe Design and Operation of Process Vents and Emission Control Systems. Hoboken, NJ: John Wiley \& Sons, Inc. https://doi.org/10.1002/0470038071

Chamizo, J. A. (2010). Historia y Filosofía de la Química. Siglo XXI Editores. https://doi.org/10.17227/01203916.171

Chin, W. (2019). Technology, War and the State: Past, Present and Future. International Affairs, 95, 765-783. https://doi.org/10.1093/ia/iiz106

Coetzee, J. J., Bansal, N., \& Chirwa, E. M. N. (2018). Chromium in Environment, Its Toxic Effect from Chromite-Mining and Ferrochrome Industries, and Its Possible Bioremediation. Exposure and Health, 12, 51-62. https://doi.org/10.1007/s12403-018-0284-z

Duarte, D. F. (2005). Una historia breve del opio y de los opioids. Revista Brasileira de Anestesiologia, 55, 135-146. https://doi.org/10.1590/S0034-70942005000100015

García, C. E., \& Arango, P. R. (2010). La Neutralidad Valorativa de la Ciencia y el Conflicto Entre la Razón y las Pasiones. Discusiones Filosóficas, 17, 223-237.

García, M. A., Olry de Labry Lima, A., Ferrer Lopez, I., \& Bermúdez-Tamayo, C. (2018). Analysis of Changes in Trends in the Consumption Rates of Benzodiazepines and Benzodiazepine-Related Drugs. Journal of Pharmaceutical Policy and Practice, 11, Article No. 1. https://doi.org/10.1186/s40545-017-0128-4

Gavroglu, K. (2009). Questioning the Neutrality of Science. Hitorien, 9, 93-100. https://doi.org/10.12681/historein.25

Godard, O. (2013). The Precautionaty Principle and Chemical Risk. In J. Llored (Ed.), The Philosophy of Chemistry: Practices, Methodologies, and Concepts (pp. 65-96). Cambridge: Cambridge Scholars Publishing.

Herzberg, D., Guarino, H., Mateu-Gelabert, P., \& Bennett, A. S. (2016). Recurring Epidemics of Pharmaceutical Drug Abuse in America: Time for an All-Drug Strategy. American Journal of Public Health, 106, 408-410. https://doi.org/10.2105/AJPH.2015.302982

Hider-Mlynarz, K., Cavalié, P., \& Maison, P. (2018) Trends in Analgesic Consumption in France over the Last 10 Years and Comparison of Patterns across Europe. BJCP British Journal of Clinical Pharmacology, 84, 1324-1334. https://doi.org/10.1111/bcp.13564

Hoffman, J. S., \& Wells, J. B. (1989). Environmental Regulations on Chlorofluorocarbons. International Journal of Thermophysics, 10, 535-544. https://doi.org/10.1007/BF00507976

Hull, S. P. (2018). Sinaloa World: The Dark Mirror of the Global Drugs Trade. CLAMANTIS: The MALS Journal, 1, Article 4.

ICH Harmonised Tripartite Guideline (2006). Impurities in New Drug Substances Q3A (R2). In International Conference on Harmonisation of Technical Requirements for 
Registration of Pharmaceuticals for Human Use (Vol. 4, pp. 1-15). United Kingdom: European Medicines Agency.

Kasa, S. (2008). Industrial Revolutions and Environmental Problems. In W. Ostreng (Ed.), Confluence Interdisciplinary Communications 2007/2008 (pp. 70-75). Oslo: Centre for Advanced Study at the Norwegian Academy of Science and Letters.

Kovac, J. (2006). Professional Ethics in Science. In D. Baird, E. Scerri, \& L. McIntyre (Eds.), Philosophy of Chemistry (pp. 157-169). Boston Studies in the Philosophy of Science Vol. 242, Dordrecht: Springer.

Kümmerer, K. (2007). Sustainable from the Very Beginning: Rational Design of Molecules by Life Cycle Engineering as an Important Approach for Green Pharmacy and Green Chemistry. Green Chemistry, 9, 899-907. https://doi.org/10.1039/b618298b

Lafferty, L., Hunter, T. S., \& Marsh, W. A. (2006). Knowledge, Attitudes and Practices of Pharmacists Concerning Prescription Drug Abuse. Journal of Psychoactive Drugs, 38, 229-232. https://doi.org/10.1080/02791072.2006.10399848

Leach, J. (1968). Explanation and Value Neutrality. The British Journal for the Philosophy of Science, 19, 93-108. https://doi.org/10.1093/bjps/19.2.93

Leonardi, M., Villacampa, M., \& Menéndez, J. C. (2018). Multicomponent Mechanochemical Synthesis. Chemical Science, 9, 2042-2064. https://doi.org/10.1039/C7SC05370C

Lipshutz, B., Gallou, F., \& Sachin, H. (2016). Evolution of Solvents in Organic Chemistry. ACS Sustainable Chemistry \& Engineering, 4, 5838-5849. https://doi.org/10.1021/acssuschemeng.6b01810

Lucas, R. E. (2003). The Industrial Revolution Past and Future. Annual Report, Federal Reserve Bank of Minneapolis, 18, 5-20.

Morris, P. (2007). A Personal Historiography of the Chemical Industry since 1956. Bulletin for the History of Chemistry, 32, 10-20.

Motorina, L. (2014). Concept of Science in Kantian Philosophy (pp. 40-46). Moscow: National Research University, Russia.

Nriagu, J. (1990). The Rise and Fall of Leaded Gasoline. The Science of the Total Environment, 92, 13-28. https://doi.org/10.1016/0048-9697(90)90318-O

Olivé, L., \& Pérez-Tamayo, R. (2012). Temas de ética y epistemología de la Ciencia. Diálogos entre un filósofo y un científico. Fondo de Cultura Económica, México, 111.

Paseta, L., Grégory, P., Sorribas, S., \& Coronas, J. (2016). Solventless Synthesis of MOFs at High Pressure. ACS Sustainable Chemistry \& Engineering, 4, 3780-3785. https://doi.org/10.1021/acssuschemeng.6b00473

Resnik, D. B., \& Elliott, K. C. (2016). The Ethical Challenges of Socially Responsible Science. Accountability in Research: Policies and Quality Assurance, 23, 31-46. https://doi.org/10.1080/08989621.2014.1002608

Russel, B. (1997). Religion and Science. New York: Oxford University Press.

Schmitz, R. (1985). Friedrich Wilhelm Sertürner and the Discovery of Morphine. Pharmacy in History, 27, 61-74.

Schummer, J. (2004). The Philosophy of Chemistry. Infancy toward Maturity, 2, 1-22.

Setzen, M. (2008). Driving Impact-Closing the Plastic Cycle. Schönberg: Sesotec GmbH. https://www.sesotec.com/emea/en/drivingimpact-closing-the-plastic-cycle

Spratt, T. (2003). History of Royal Society. Whitefish, MT: Kessinger Publishing.

Strömland, K., Philipson, E., \& Andersson, M. (2002). Offspring of Male and Female Parents with Thalidomide Embryopathy: Birth Defects and Functional Anomalies. Te- 
ratology, 66, 115-121. https://doi.org/10.1002/tera.10083

Stump, D. J. (2002). From the Values of Scientific Philosophy to the Value Neutrality of the Philosophy of Science. In M. Heidelberger, \& F. Stadler (Eds.), History of Philosophy of Science. Vienna Circle Institute Yearbook [2001] (Institut "Wiener Kreis" Society for the Advancement of the Scientific World Conception) (Vol. 9, pp. 147-158). Dordrecht: Springer.

Tarlock, A. D. (2009). History of Environmental Law, Environmental Laws and Their Enforcement(Vol. I). EUA.

Telles, A. (2019). Mothers, Warriors and Lords: Gender(ed) Cartographies of the US War on Drugs in Latin America. Contexto Internacional, 41, 15-38. https://doi.org/10.1590/s0102-8529.2019410100002

Thomas-Hillman, I., Laybourn, A., Dodds, C., \& Kingman, S. (2018). Realising the Environmental Benefits of Metal-Organic Frameworks: Recent Advances in Microwave Synthesis. Journal of Materials Chemistry A, 6, 11564-11581.

https://doi.org/10.1039/C8TA02919A

Verdugo-Serna, C. (1997). El Mito de la Neutralidad Valorativa de la Ciencia. Diálogo Iberoamericano, 10, 18.

Wolpe, P. (2006). Reasons Scientists Avoid Thinking about Ethics. Cell, 125, 1023-1025. https://doi.org/10.1016/j.cell.2006.06.001

Zee, A. (2009). The Promotion and Marketing of OxyContin: Commercial Triumph, Public Health Tragedy. American Journal of Public Health, 99, 221-227.

https://doi.org/10.2105/AJPH.2007.131714 